\title{
U-Pb Zircon Age Data for Selected Sedimentary, Metasedimentary, and Igneous Rocks from Northern and Central Alaska
}

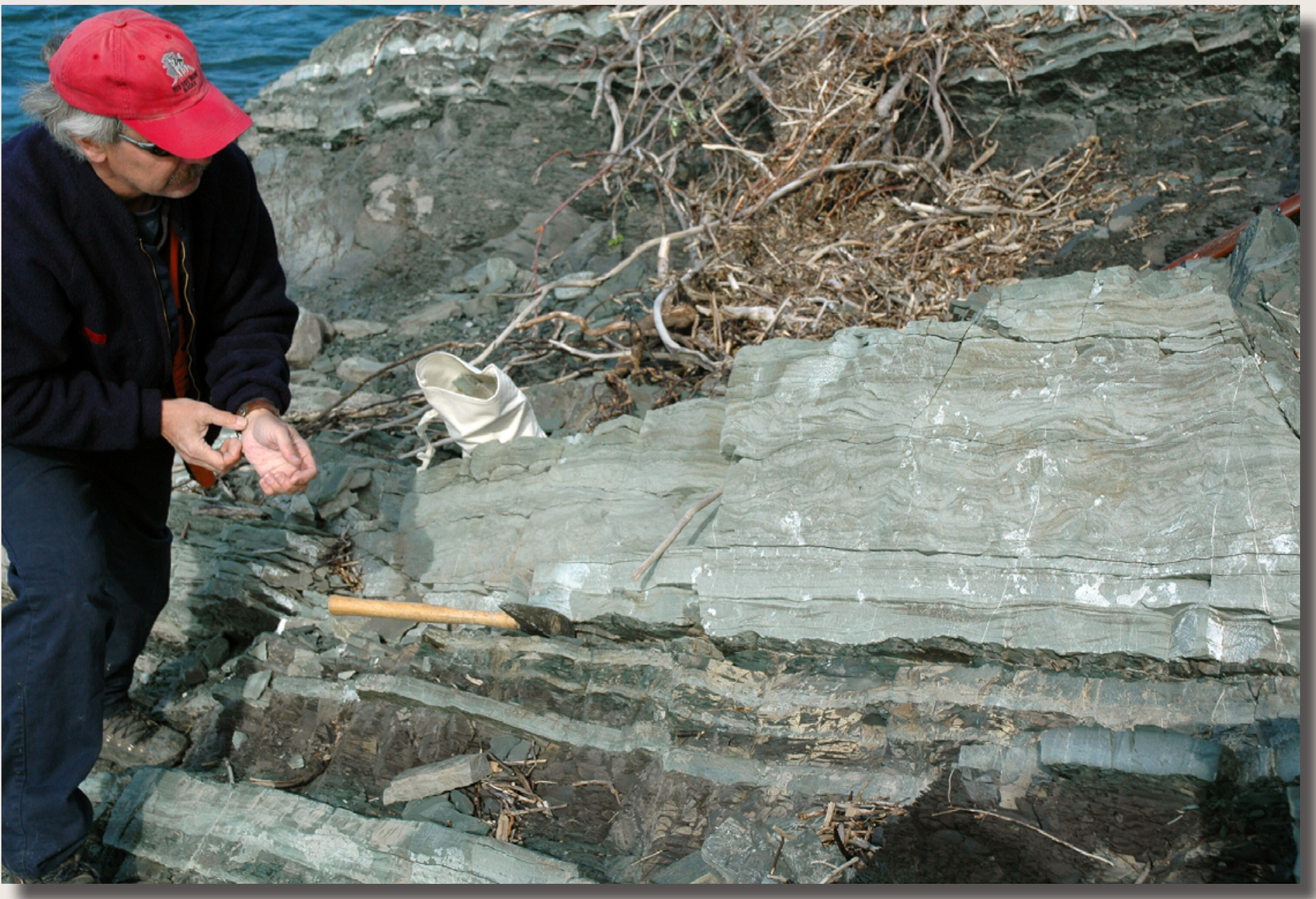

Data Series 899 
FRONT COVER

U.S. Geological Survey geologist Christopher J. Potter sampling Upper Jurassic sandstone turbidites of unit Jw of Curtis and others (1984) for detrital zircon U-Pb analysis, Katakturuk River, western Brooks Range. Photograph by Thomas E.

Moore. 


\section{U-Pb Zircon Age Data for Selected Sedimentary, Metasedimentary, and Igneous Rocks from Northern and Central Alaska}

By Thomas E. Moore

Data Series 899 


\section{U.S. Department of the Interior SALLY JEWELL, Secretary}

\section{U.S. Geological Survey \\ Suzette M. Kimball, Acting Director}

U.S. Geological Survey, Reston, Virginia: 2014

For more information on the USGS - the Federal source for science about the Earth, its natural and living resources, natural hazards, and the environment—visit http://www.usgs.gov or call 1-888-ASK-USGS

For an overview of USGS information products, including maps, imagery, and publications, visit $h t t p: / / w w w . u s g s . g o v / p u b p r o d$

To order this and other USGS information products, visit http://store.usgs.gov

Any use of trade, firm, or product names is for descriptive purposes only and does not imply endorsement by the U.S. Government.

Although this information product, for the most part, is in the public domain, it also may contain copyrighted materials as noted in the text. Permission to reproduce copyrighted items must be secured from the copyright owner.

Suggested citation:

Moore, T.E., 2014, U-Pb zircon age data for selected sedimentary, metasedimentary, and igneous rocks from Northern and Central Alaska: U.S. Geological Survey Data Series 899, 4 p., http://dx.doi.org/10.3133/ds899. 


\section{Contents}

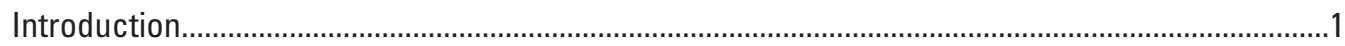

$\mathrm{U}-\mathrm{Pb}$ Analytical Techniques and Methodology Used by Apatite to Zircon, Inc................................1

Mineral Separation ................................................................................................................

Laser Ablation Inductively Coupled Plasma Mass Spectrometry (LA-ICP-MS) .......................2

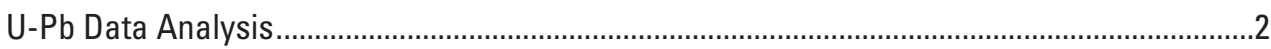

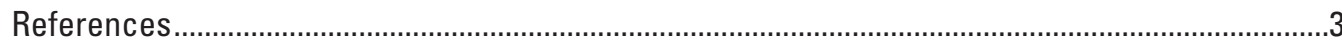

\section{Tables}

[Available for download at http://pubs.usgs.gov/ds/0899/]

1. Complete laser ablation inductively coupled plasma mass spectrometry detrital zircon U-Pb analytical data from sample DDH-796 from the Upper Mississippian Ikalukrok unit of the Kuna Formation in the Red Dog Mineral District, western Brooks Range, Alaska discussed in Dumoulin and others (2013).

2. Complete laser ablation inductively coupled plasma mass spectrometry zircon $\mathrm{U}-\mathrm{Pb}$ analytical data from various units of the Brookian sequence, western Brooks Range, Alaska discussed in Moore and others (in press). 



\title{
U-Pb Zircon Age Data for Selected Sedimentary, Metasedimentary, and Igneous Rocks from Northern and Central Alaska
}

\author{
By Thomas E. Moore
}

\section{Introduction}

This publication contains the complete results of $\mathrm{U}-\mathrm{Pb}$ zircon age dating studies of sedimentary and metasedimentary units from northern and central Alaska that are discussed and interpreted in other reports by the author. Most of the U-Pb ages are of detrital zircons from sandstones, although $\mathrm{U}-\mathrm{Pb}$ ages from igneous and sedimentary clasts from conglomerates in some of those same units are also included. In addition to the data presented in the interpretive reports, this publication includes data that were excluded due to discordance, analytical problems, and publication space limitations. The $\mathrm{U}-\mathrm{Pb}$ age data are reported in Excel-file format so that they can be easily downloaded and referenced or reinterpreted by future workers.

Data from two studies are included in this report. The first study, by Dumoulin and others (2013), reported the detrital zircon $\mathrm{U}-\mathrm{Pb}$ age analysis of a single sample from the Upper Mississippian Ikalukrok unit of the Kuna Formation (table 1). The second study is that of Moore and others (in press), which focuses on the Upper Jurassic and Lower Cretaceous part of the Brookian sequence in the western Brooks Range (17 samples; table 2). For the latter study, samples were analyzed from the following units (1) the Upper Jurassic unit, Jw, of Curtis and others (1984), (2) the Lower Cretaceous Igrarok Hills unit of Moore and others (2002), (3) the Upper Jurassic and Lower Cretaceous Okpikruak Formation, (4) the Lower Cretaceous lower Brookian shale of Mull (1995), (5) the Lower Cretaceous Mount Kelly Graywacke Tongue of the Fortress Mountain Formation, (6) and the upper Lower Cretaceous Nanushuk Formation as redefined by Mull and others (2003). The results for each study are reported in separate Excel files, with individual samples in each study being shown as separate sheets within the files. The analyses of individual zircons are listed separately on the sheet according to the filtering schemes of the study and by the type of mass spectrometer used.

\section{$\mathrm{U}-\mathrm{Pb}$ Analytical Techniques and Methodology Used by Apatite to Zircon, Inc.}

All of the analyses reported here were conducted by Apatite to Zircon, Inc., located in Viola, Idaho. The analytical techniques and methodology used for U-Pb age dating by Apatite to Zircon, Inc. have been discussed in Dumoulin and others (2013), Hults and others (2013), and Moore and others (in press). The following paragraphs, written mainly by proprietors Raymond A. Donelik and Paul B. O'Sullivan, provide a synthesis of the U-Pb age dating procedures reported in these publications.

\section{Mineral Separation}

Samples were crushed using a jaw crusher and sieved through 300- $\mu \mathrm{m}$ nylon mesh. Lithium polytungstate and a centrifuge were used to produce heavy mineral concentrate separations to ensure that zircon grains were not inadvertently washed away during the separation process, as can happen with conventional techniques that use a Wilfley or Gemini table. Diiodomethane and standard magnetic separation processes were then used to separate zircon grains from the heavy mineral concentrate. The separation procedure produced thousands of zircons from a sample that initially weighed about 1 kilogram.

Following separation, zircon standards and unknowns were mounted in $1-\mathrm{cm}^{2}$ epoxy wafers and ground down to expose internal grain surfaces before final polishing. Grains and the locations for laser spots on these grains were selected using a high power optical microscope with transmitted light. This method was used instead of cathodoluminescence 2-D imaging because it allows the recognition of features such as inclusions and cracks below the surface of individual grains that could otherwise result in spurious isotopic counts. One 
hundred grains were selected, some of which were chosen to represent the variation of sizes, colors, and morphologies of the zircons present in the sample. A larger fraction of the grains were selected by random process. This methodology captures the ages of the broad range of zircon types present, as well as providing a measure of their relative abundances.

\section{Laser Ablation Inductively Coupled Plasma Mass Spectrometry (LA-ICP-MS)}

$\mathrm{U}-\mathrm{Pb}$ analysis was conducted by LA-ICP-MS at two laboratories. Most of the data were determined at the Washington State University Geoanalytical Laboratory in Pullman, Wash. (for example, Chang and others, 2006) prior to October 2012, and the remainder of the analyses were completed at the laboratories of Apatite to Zircon, Inc. in Viola, Idaho after that date.

For the U-Pb analyses performed at the Washington State Geoanalytical Laboratory, approximately 80 to 105 grains per sample were analyzed on a New Wave YAG 213-nm laser ablation (LA) system in line with a Finnigan Element2 magnetic sector, inductively coupled plasma mass spectrometer (ICP-MS). All analyses, including standards and unknowns, were performed using a $20-\mu \mathrm{m}$ spot. Following approximately 6 seconds of background data collection, laser ablation commenced and signal data were collected by scanning repeatedly across the masses (in atomic mass units): 202, 204, 206, 207, 208, 232, 235, and 238. Ablated material was transported to the plasma line using He; Ar was the plasma gas. A total of 250 data scans were collected for each zircon spot analyzed, and consisted of (1) approximately 55 background scans, (2) approximately 20 transition scans between background and background plus signal, and (3) approximately 175 background plus signal scans. Four standard spots were analyzed prior to and following each group of approximately 25-30 unknown sample spots to correct for machine fluctuations and to determine fractionation factors. Common $\mathrm{Pb}$ correction was made using the measured ${ }^{204} \mathrm{~Pb}$ content and assuming an initial $\mathrm{Pb}$ composition from Stacey and Kramers (1975).

Analyses conducted at the laboratories of Apatite to Zircon, Inc. in Viola, Idaho were determined on an Agilent 7700x quadrapole mass spectrometer attached to a Resonetics RESOlution M-50 Eximer laser. All analyses, including standards and unknowns, were performed using a $26-\mu \mathrm{m}$ spot. A total of 47 data scans were collected for each zircon spot analyzed, including (1) approximately 6 background scans, (2) approximately 3 transition scans between background and background plus signal, and (3) approximately 38 background plus signal scans. A total of 35 different isotopes were scanned, ranging from ${ }^{24} \mathrm{Mg}$ to ${ }^{238} \mathrm{U}$. Approximately 28 seconds were allowed between each analysis in order to clear the system prior to the next background data collection. Ablated material was transported to the plasma line using ultra-high purity He gas; ultra-high purity Ar was the plasma gas. A total of 26 standard spots were analyzed at the beginning, middle, and end of the session; an additional 13 standard spots were analyzed prior to and following each group of 15 unknown sample spots to correct for machine fluctuations and constrain fractionation factors. Fractionation factors were calculated based on the following assumptions, (1) ${ }^{235} \mathrm{U}$ values were calculated from measured ${ }^{238} \mathrm{U}$ values (Steiger and Jäger, 1977), and (2) zero fractionation was assumed between ${ }^{206} \mathrm{~Pb}$ and ${ }^{207} \mathrm{~Pb}$. The Stacey and Kramers (1975) common $\mathrm{Pb}$ model for Earth was used. Ages and common $\mathrm{Pb}$ ratios were determined iteratively using a pre-set, session-wide minimum common $\mathrm{Pb}$ age value (the default minimum common $\mathrm{Pb}$ age was set equal to the age of the oldest age standard in current session).

Uncertainties are calculated as asymmetric errors that were generated from the standards employed in the analysis and fractionation factors, as well as those caused by machine error. The most precise age from the concordant-scanweighted ratio ${ }^{207} \mathrm{~Pb} /{ }^{235} \mathrm{U},{ }^{206} \mathrm{~Pb} /{ }^{238} \mathrm{U}$ or ${ }^{207} \mathrm{~Pb} /{ }^{206} \mathrm{~Pb}$ was selected as the preferred age.

\section{U-Pb Data Analysis}

Previous LA-ICP-MS studies of U-Pb zircon dating used the so-called intercept method, which assumes that isotopic ratio varies linearly with scan number due solely to linearly varying isotopic fractionation (Chang and others, 2006; Gehrels and others, 2008). The data modeling approach favored here is the modeling of background-corrected signal intensities for each isotope at each scan. Background intensity for each isotope was calculated using a fitted line (for decreasing background intensity) or using the arithmetic mean (for nondecreasing background intensity), at the global minimum of selected isotopes $\left({ }^{206} \mathrm{~Pb},{ }^{232} \mathrm{Th}\right.$, and $\left.{ }^{238} \mathrm{U}\right)$ for the spot. Background plus signal intensity for each isotope at each scan was calculated using the median of fitted ( $2^{\text {nd }}-$ order polynomial) intensity values for a moving window ( 7 scans wide) that includes the scan. The precision of each background-corrected signal intensity value was calculated from the precision of background intensity value and the precision of the background plus signal intensity value. Zircon $\mathrm{U}-\mathrm{Pb}$ age standards include the $1099 \pm 0.6 \mathrm{Ma}$ FC zircon (FC-1 of Paces and Miller, 1993) used here as the primary age standard. Isotopic data for $\mathrm{FC}$ were used to calculate $\mathrm{Pb} / \mathrm{U}$ fractionation factors and their absolute errors for each FC data scan at each FC spot; these fractionation factors were smoothed session-wide for each data scan using the median of fitted ( $1^{\text {st }}$-order polynomial) fractionation factor values for a moving window (11 FC spots wide) that includes the current FC spot and scan. Under the operating conditions of the LA-ICP-MS sessions in this study, fractionation factors were found to vary strongly with scan number, decreasing with increasing scan number (presumably due to increasing ablation pit depth and the effect this had on fractionation; for example, Paton and others, 2010). The zircon crystal lattice is widely 
known to accumulate $\alpha$-radiation damage (for example, Zhang and others, 2009 and references therein). It was assumed here that increased $\alpha$-damage in a zircon leads to a decrease in the hardness of the zircon; this in turn leads to a faster rate of laser penetration into the zircon during ablation, leading to dependence of isotopic fractionation on the degree of zircon lattice radiation damage. Ages calculated for all zircon age standards, when those standards were treated as unknowns, were used to construct a fractionation factor correction curve (exponential form) in terms of accumulated radiation damage. The notion of matrix-matched zircon standard and zircon unknown has been proposed largely on the basis of trace element chemistry (for example, Black and others, 2004). In this study, time and lattice damage, parameters invisible to instruments used to characterize trace element chemistry, were introduced and applied based on measured $\mathrm{U}$ and Th chemistries to effectively matrix-match standard and unknown zircons.

Uranium decay constants and the ${ }^{238} \mathrm{U} /{ }^{235} \mathrm{U}$ isotopic ratio reported in Steiger and Jäger (1977) were used for the analyses. Errors for the isotopic ratios ${ }^{207} \mathrm{~Pb} /{ }^{235} \mathrm{U}_{\mathrm{c}}\left({ }^{235} \mathrm{U}_{\mathrm{c}}=137.88^{238} \mathrm{U}\right)$, ${ }^{206} \mathrm{~Pb} /{ }^{238} \mathrm{U}$, and ${ }^{207} \mathrm{~Pb} /{ }^{206} \mathrm{~Pb}$ at each scan included errors from the background-corrected signal values for each isotope, the fractionation factor error, and an additional relative error term required to force 95 percent of the $\mathrm{FC}$ ages to be concordant. Ages for the ratios ${ }^{207} \mathrm{~Pb} /{ }^{235} \mathrm{U}_{\mathrm{c}},{ }^{206} \mathrm{~Pb} /{ }^{238} \mathrm{U}$, and ${ }^{207} \mathrm{~Pb} /{ }^{206} \mathrm{~Pb}$ were calculated for each data scan and checked for concordance; concordance here was defined as overlap of all three ages at the $1 \sigma$ level (the use of $2 \sigma$ level was found to skew the results to include scans with any significant common $\mathrm{Pb}$ ). If the number of concordant data scans for a spot was greater than zero, the more precise age from the concordant-scan-weighted ratio ${ }^{207} \mathrm{~Pb} /{ }^{235} \mathrm{U}_{\mathrm{c}},{ }^{206} \mathrm{~Pb} /{ }^{238} \mathrm{U}$ or ${ }^{207} \mathrm{~Pb} /{ }^{206} \mathrm{~Pb}$ (listed under the header, "Age Type" in tables 1 and 2) was chosen as the preferred age. Although other workers suggest a rule-of-thumb preference for ${ }^{206} \mathrm{~Pb} /{ }^{238} \mathrm{U}$ for grain ages less than $1000 \mathrm{Ma}$, and ${ }^{207} \mathrm{~Pb} /{ }^{206} \mathrm{~Pb}$ for grain ages greater than $1000 \mathrm{Ma}$ (for example, Gehrels, 2000), the above method of selecting the most precise concordant age on a grain-by-grain basis has been accepted for use in the U-Pb data sets reported here. Asymmetrical negative-direction and positive-direction age errors were calculated by subtracting and adding, respectively, the isotopic ratio errors in the appropriate age equation.

\section{References}

Black, L.P., Kamo, S.L., Allen, C.M., Davis, D.W., Aleinikoff, J.N., Valley, J.W., Mundil, R., Campbell, I.H., Korsch, R.J., Williams, I.S., and Foudoulis, C., 2004, Improved ${ }^{206} \mathrm{~Pb} /{ }^{238} \mathrm{U}$ microprobe geochronology by the monitoring of traceelement-related matrix effect; SHRIMP, ID-TIMS, ELAICP-MS and oxygen isotope documentation for a series of zircon standards: Chemical Geology, v. 205, p. 15-140.
Chang, Z., Vervoort, J.D., McClelland, W.C., and Knaack, C., 2006, U-Pb dating of zircon by LA-ICP-MS: Geochemistry, Geophysics, Geosystems, v. 7, no. 5, 14 p.

Curtis, S.M., Ellersieck, I., Mayfield, C.F., and Tailleur, I.L., 1984, Reconnaissance geologic map of southwestern Misheguk Mountain quadrangle, Alaska: U.S. Geological Survey Miscellaneous Investigations Series Map I-1502, scale $1: 63,360$.

Dumoulin, J.A., Johnson, C.A., Slack, J.F., Bird, K.J., Whalen, M.T., Moore, T.E., Harris, A.G., and O'Sullivan, P.B., 2013, Carbonate margin, slope, and basin facies of the Lisburne Group (Carboniferous-Permian) in northern Alaska, in Verwer, K., Playton, T., and Harris, P., eds., Deposits, Architecture, and Controls of Carbonate Margin, Slope, and Basin Systems: SEPM Special Publication No. 105, p. 211-236, doi:10.2110/sepmsp.105.02.

Gehrels, G.E., 2000, Introduction to detrital zircon studies of Paleozoic and Triassic strata in western Nevada and northern California, in Soreghan, M.J., and Gehrels, G.E., eds., Paleozoic and Triassic paleogeography and tectonics of western Nevada and northern California: Geological Society of America Special Paper 347, p. 1-17.

Gehrels, G.E., Valencia, V.A., and Ruiz, J., 2008, Enhanced precision, accuracy, efficiency, and spatial resolution of $\mathrm{UPb}$ ages by laser ablation-multicollector-inductively coupled plasma-mass spectrometry: Geochemistry Geophysics Geosystems, v. 9, 13 p.

Hults, C.P., Wilson, F.H., Donelick, R.A., and O'Sullivan, P.B., 2013, Two flysch belts having distinctly different provenance suggest no stratigraphic link between Wrangellia composite terrane and the paleo-Alaskan margin: Lithosphere, v. 5, p. 575-594, doi: 10.1130/L310.1.

Moore, T.E., Dumitru, T.A., Adams, K.E., Witebsky, S.N., and Harris, A.G., 2002, Origin of the Lisburne Hills-Herald arch structural belt-Stratigraphic, structural, and fission-track evidence from the Cape Lisburne area, northwestern Alaska, in Miller, E.L., and Grantz, A., eds., Tectonic evolution of the Bering Shelf-Chukchi Sea-Arctic Margin and adjacent landmasses: Geological Society of America Special Paper 360 , p. $77-109$.

Moore, T.E., O’Sullivan, P.B., Potter, C.J., and Donelick, R.A., in press, Provenance and detrital zircon geochronologic evolution of Lower Brookian foreland basin deposits of the western Brooks Range, Alaska, and implications for early Brookian tectonism: Geosphere, $114 \mathrm{~ms}$ p.

Mull, C.G., 1995, Preliminary evaluation of the hydrocarbon source rock potential of the Tingmerkpuk Sandstone (Neocomian) and related rocks, northwestern De Long Mountains, Brooks Range, Alaska: Division of Geological and Geophysical Surveys Public-Data File 95-30, 20 p. 
Mull, C.G., Houseknecht, D.W., and Bird, K.J., 2003, Revised Cretaceous and Tertiary stratigraphic nomenclature in the east-central Colville basin, northern Alaska: U.S. Geological Survey Professional Paper 1673, 51 p.

Paces, J.B., and Miller, J.D., 1993, Precise U-Pb ages of Duluth Complex and related mafic intrusions, northeastern Minnesota-Geochronological insights to physical, petrogenic, paleomagnetic, and tectonomagmatic processes associated with the 1.1 Ga Midcontinent Rift System: Journal of Geophysical Research, v. 98, no. B8, p. 13997-14013.

Paton, C., Woodhead, J.D., Hellstrom, J.C., Hergt, J.M., Greig, A., and Maas, R., 2010, Improved laser ablation $\mathrm{U}-\mathrm{Pb}$ zircon geochronology through robust downhole fractionation correction: Geochemistry, Geophysics, Geosystems, v. 11, doi:10.1029/2009GC002618.
Stacey, J.S., and Kramers, J.D., 1975, Approximation of terrestrial lead isotope evolution by a two-stage model: Earth and Planetary Science Letters, v. 26, p. 207-221.

Steiger, R.H., and Jäger, E., 1977, Subcommission on geochronology - Convention on the use of decay constants in geo- and cosmochronology: Earth and Planetary Science Letters, v. 36, p. 369-371.

Zhang, M., Ewing, R.C., Boatner, L.A., Salje, E.K.H., Weber, W.J., Daniel, P., Zhang, Y., and Farnan, I., 2009, $\mathrm{Pb}^{*}$ irradiation of synthetic zircon $\left(\mathrm{ZrSiO}_{4}\right)$; Infrared spectroscopic study - Reply: American Mineralogist, v. 94, p. $856-858$. 
Menlo Park Publishing Service Center, California

Manuscript approved for publication November 10, 2014

Edited by Kate Jacques

Design and layout by Cory Hurd 
